\title{
Pengaruh Perilaku Masyarakat Terhadap Kualitas Air Di Sungai Sekanak Kota Palembang
}

\author{
Herda Sabriyah Dara Kospaํ, dan Rahmadi² \\ ${ }^{1}$ Program Studi Perencanaan Wilayah dan Kota Fakultas Teknik Universitas Indo Global Mandiri; e-mail: \\ darakospa@uigm.ac.id \\ 2 Program Studi Perencanaan Wilayah dan Kota Fakultas Teknik Universitas Indo Global Mandiri;
}

\begin{abstract}
ABSTRAK
Perilaku masyarakat di sekitar bantaran sungai seperti kegiatan MCK dan membuang limbah rumah tangga langsung ke sungai memberikan dampak terhadap kualitas air sungai. Sungai Sekanak, anak Sungai Musi yang berada di Kota Palembang, telah mengalami pencemaran yang terlihat pada perubahan fisik air sungai dan hasil uji kualitas air oleh DLHK Kota Palembang. Rencana pemkot untuk mengembalikan fungsi Sungai Sekanak sebagai lokasi wisata perairan harus didukung oleh partisipasi aktif masyarakat setempat. Tujuan dari penelitian ini adalah untuk menganalisis pengaruh perilaku masyarakat terhadap kualitas air di Sungai Sekanak. Metode yang digunakan dalam penelitian ini adalah gabungan metode deskriptif kuantitatif dan kualitatif. Metode kuantitatif digunakan untuk dengan penyebaran kuesioner dan penentuan status mutu air menggunakan metode Indeks Pencemaran. Untuk mengetahui pengaruh perilaku masyarakat dalam kegiatan PHBS dan sanitasi digunakan metode kualitatif deskriptif melalui teknik triangulasi sumber data. Hasil analisis frekuensi diperoleh bahwa pengetahuan dan sikap masyarakat terhadap kegiatan PHBS dan sanitasi rata-rata sudah berjalan baik, tetapi sekitar 20 persen masyarakat belum mengimplementasikan pengetahuannya dengan masih membuang sampah langsung ke sungai. Hasil uji lab menunjukkan nilai COD, BOD, NH3$\mathrm{N}$ dan fosfat hampir di seluruh titik pengamatan telah melampaui baku mutu yang telah ditetapkan dan hasil pengukuran Indeks Pencemaran menunjukkan status mutu air Sungai Sekanak dari muara hingga ke ujung hulu mengalami kondisi cemar ringan. Hasil triangulasi data mengindikasikan bahwa terdapat pengaruh perilaku masyarakat terhadap pencemaran yang terjadi di Sungai Sekanak. Perilaku masyarakat yang masih membuang sampah ke sungai, adanya TPS-TPS ilegal yang berada di pinggiran sungai, serta belum tersedianya fasilitas IPAL komunal untuk mengolah air limbah domestik dari rumah-rumah warga menyebabkan Sungai Sekanak masih terus tercemar. Nilai COD, BOD dan amoniak yang melampui baku mutu mengindikasikan adanya pencemaran dari air limbah domestik dan industri. Selain itu, terjadinya sedimentasi akibat konversi lahan menyebabkan nilai TSS melampui baku mutu dan tingginya nilai fosfat menunjukkan adanya kandungan deterjen dalam air yang merupakan salah satu indikator dari adanya pencemaran sungai dari kegiatan MCK warga.
\end{abstract}

Kata kunci: Kualitas Air, Sumber Daya Air, Perilaku Masyarakat, Sungai Sekanak, Indeks Pencemaran

\begin{abstract}
Sekanak River has been polluted by domestic and industrial waste which can be physically witnessed and chemically measured for several parameters exceeding water quality standard. This study aims to analyse the effect of community behavior towards water quality degradation in the Sekanak River. Mix research method using both qualitative and quantitative analysis were conducted in this study. This quantitative research data was gathered through conducting a questioner survey of 100 selected households living along the riverbank. It was also used to measure the water quality status using Pollution Index (PI) Method. The descriptive qualitative component included analyzing and elaborating the actual data of community behavior toward water quality assessment using triangulation data source. The questionnaire results of the research revealed that the household's knowledge and attitude on disposal management, sanitation and hygiene at the river bank were in high level. They are generally knowledgeable, having positive attitude and also practiced good personal hygiene, but twenty percent was still throw the garbage to the river. Furthermore, a total of seven sampling station has been identified along the river. The result showed that water quality status from the upstream to the downstream had slightly polluted. It also revealed that $\mathrm{COD}, \mathrm{BOD}, \mathrm{NH}_{3}-\mathrm{N}$ and Phosphate have exceeded the allowable threshold levels. This may attributed to the anthropogenic activities such as washing and throwing garbage which can be indicated from changing in the levels of COD and phosphate. However, water pollution inevitably occurs due to the unavailability of communal wastewater treatment plant, poor waste management and lack of public stimulus such as incentive and punishment to protect the river. Beside technical aspect, resolve complex socioecological issues are important components of a long-term environmental strategy. It is recommended that education, legislation and incentivization are necessary to spur and improve community awareness and potential as "river guards".
\end{abstract}

Keywords: water quality, water resource, community behavior, Sekanak River, pollution index

Citation: Kospa, H. S. D., dan Rahmadi. (2019). Pengaruh Perilaku Masyarakat Terhadap Kualitas Air Di Sungai Sekanak Kota Palembang Jurnal Ilmu Lingkungan, 17(2), 212-221 doi:10.14710/jil.17.2.212-221 


\section{Latar Belakang}

Perubahan pola konsumsi masyarakat terjadi akibat semakin tingginya jumlah populasi penduduk dan laju perkembangan perkotaan. Dengan luas lahan yang tetap, kondisi tersebut mengakibatkan terjadinya penurunan daya dukung lingkungan. Di samping itu, perubahan atau degradasi pada lingkungan hidup juga disebabkan oleh perilaku masyarakat (Susilo, 2012). Aktivitas yang dilakukan oleh rumah tangga, pertanian dan industri tentunya menimbulkann limbah yang jika tidak diolah dengan baik akan memberi dampak pada penurunan kualitas lingkungan (Suriawiria, 2003).

Penurunan kualitas lingkungan dalam hal ini degradasi air adalah dampak dari limbah buangan yang belum diolah ke badan sungai yang tidak terkendali. Tingginya aktivitas pembangunan di sepanjang sungai menyebabkan daya dukung sungai terhadap polutan tidak sesuai. Berdasarkan Supratiwi (2014) bahwa sekitar 60 hingga 70 persen pencemaran sungai disebabkan oleh limbah domestik, sedangkan limbah yang dapat diolah hanya 6,1 persen. Walaupun penurunan pencemaran sungai akibat limbah industri telah mencapai 40 persen, tingginya kontribusi limbah rumah tangga menyebabkan sungai masih terus tercemar.

Palembang pernah dijuluki Venesia dari Timur karena menjadikan sungai sebagai sarana transportasi dan aktivitas ekonomi masyarakat. Berdasarkan sejarah tersebut, Pemerintah Kota Palembang berencana untuk mengembalikan fungsi sungai dengan menormalisasi dan merestorasi sungai-sungai di Palembang. Kegiatan ini diawali dengan merestorasi Sungai Sekanak dengan tujuan untuk menjadikan sungai ini sebagai lokasi wisata perairan (Inge, 2017).

Sungai Sekanak merupakan anak Sungai Musi yang terletak di Kota Palembang dengan total luas daerah aliran $11,40 \mathrm{~km}^{2}$. Sungai ini merupakan bagian dari sistem drainase yang terdiri dari sembilan belas sistem yang ada di Wilayah Kota Palembang (BLH Kota Palembang, 2012). Sungai Sekanak memiliki muara di Pasar Sekanak dan hulu hingga ke Jalan Soekarno Hatta.

Menurunnya kualitas perairan dapat disebabkan oleh sumber-sumber pencemar yang masuk ke badan air. Umumnya kajian-kajian terdahulu mengenai kualitas air lebih menekankan pada kandungan bahan pencemar di badan air,, sedangkan penelitian ini mengembangkan penelitian terdahulu dengan memperluas parameter pada sumber bahan pencemar sehubungan dengan perilaku masyarakat dalam kegiatan sanitasi dan PHBS.

Permukiman di sekitar Sungai Sekanak merupakan permukiman padat penduduk, dimana rata-rata jarak antara rumah dengan sempadan sungai tidak sesuai dengan Peraturan Menteri PUPR No.28/PRT/M 2015, selain itu di bagian tengah sungai terdapat rusun berbentuk blok-blok yang juga menyumbang limbah rumah tangga menuju satu arah, yaitu ke sungai. Masyarakat yang tinggal di bantaran sungai memanfaatkan Sungai Sekanak untuk membuang limbah domestik, seperti MCK, perdagangan dan industri. Sebagai dampak dari kegiatan masyarakat tersebut, Sungai Sekanak mengalami pencemaran, dimana terjadi perubahan fisik air diantaranya perubahan pada warna air sungai yang kehitaman dan berbau menyengat. Jika hal ini terus berlanjut, selain masalah kesehatan yang lebih kompleks, maka tujuan menjadikan Sungai Sekanak sebagai wisata perairan dan transportasi sulit untuk diwujudkan.

Berdasarkan hasil analisis laboratorium yang dilakukan oleh Dinas Lingkungan Hidup dan Kebersihan Palembang tahun 2017, status mutu air Sungai Sekanak mengalami cemar sedang dengan beberapa parameter yang tidak memenuhi baku mutu air sungai kelas I Peraturan Gubernur Sumatera Selatan No.16 Tahun 2015. Parameter tersebut antara lain nilai TSS, COD, BOD, natrium dan fosfat. Parameter-parameter tersebut menunjukkan bahwa tingginya konsentrasi bahan organik pada air sungai yang dapat diakibatkan oleh pencemaran yang berasal dari limbah domestik seperti deterjen, limbah industri dan pertanian (Yohanes et al, 2014).

Berdasarkan uraian tersebut, penting untuk dilakukan analisis mendalam mengenai bagaimana perilaku masyarakat yang bermukim di dekat sungai dan pengaruhnya terhadap kualitas air sungai tersebut karena kunci keberhasilan dari pelestarian sumber daya alam adalah adanya partisipasi aktif dari masyarakat setempat. Penelitian ini akan mengkaji mengenai perilaku masyarakat yang bermukim di bantaran Sungai Sekanak dalam kegiatan sanitasi maupun perilaku hidup bersih dan sehat (PHBS) dan pengaruhnya terhadap kualitas air Sungai Sekanak yang akan diuji dari aspek fisika, kimiawi dan biologinya. Melalui studi ini diharapkan dapat menjadi bahan dalam perumusan strategi dalam menormalisasi air sungai dengan meningkatkan kesadaran dan potensi masyarakat sebagai guardian of river atau "penjaga sungai". .

Perilaku masyarakat menjadi penentu dari kualitas air sungai.

\section{Kajian Literatur}

\subsection{Perilaku Hidup Bersih dan Sehat}

Merujuk pada teori yang dikemukakan oleh Benyamin Bloom terdapat tiga domain perilaku manusia dalam konteks untuk tujuan pendidikan, yaitu kognitif, afektif dan psikomotorik. Kemudian teori ini dikembangkan dengan memodifikasi untuk tujuan hasil pendidikan kesehatan, yaitu pengetahuan, sikap dan tindakan (Notoatmodjo, 2007)

a. Aspek Pengetahuan

Pengetahuan merupakan hasil tahu berdasar pengalaman pribadi atau tanpa pengalaman dari orang lain.

b. Aspek Sikap 
Kecenderungan bertingkah laku berdasarkan penilaian yang bersifat positif/negatif pada objek tertentu.

c. Aspek Tindakan

Menerapkan serangkaian perilaku sebagai hasil pembelajaran yang menjadikan individu, keluarga, kelompok atau masyarakat dapat berdiri sendiri di bidang kesehatan dan berkontribusi aktif dalam menciptakan kesehatan masyarakat disebut dengan Perilaku Hidup Bersih dan Sehat atau yang sering disingkat PHBS. Adapun melalui program PHBS diharapkan dapat menambah pengetahuan, kesadaran dan keinginan masyarakat untuk menjalankan hidup sehat, serta sebagai upaya mewujudkan derajat hidup optimal melalui peningkatan peran aktif seluruh stakeholder yang terlibat, yaitu masyarakat, swasta dan dunia usaha (Depkes, RI, 2007).

Kemenkes pada tahun 2013 menyatakan bahwa PHBS di lingkungan keluarga memiliki beberapa indikator diantaranya yang terkait dalam penelitian ini adalah:

a. Menggunakan air bersih dan sehat

Air adalah komponen sanitasi yang paling vital dalam menentukan status kesehatan seseorang. Berbagai penyakit dan resiko kesehatan ditularkan melalui media air, seperti bakteri, virus, dan bahan-bahan kimia berbahaya. Oleh karena itu, menggunakan air yang bersih dan sehat menjadi komponen yang sangat dipertimbangkan.

b. Mencuci tangan menggunakan sabun sebelum makan, setelah dari toilet, atau sehabis bekerja dapat mencegah terjadinya infeksi bakteri dan virus.

c. Menggunakan jamban sehat

Jamban adalah fasilitas sanitasi yang dapat menggambarkan kondisi perilaku hidup bersih dan sehat suatu keluarga. Menggunakan jamban yang sehat dan memenuhi syarat dapat mencegah terjadinya kontaminasi silang hasil ekskreta manusia ke sumber air dan makanan dalam keluarga.

\subsection{Kualitas Air}

Menurut Yuliastuti (2011) sifat dari air, serta kandungan organisme, zat, energi atau komponen lain di dalam air merupakan definisi dari kualitas air. Di samping itu, Fitriyana (2004) menjelaskan pengertian kualitas air sebagai limit kandungan parameter-parameter air yang ditentukan bagi kelayakan untuk penggunaan tertentu. Batas-batas konsentrasi tersebut ditentukan berdasarkan pertimbangan ilmiah yang diperoleh dari hasil-hasil riset. Adapun standar baku mutu kualitas air diatur oleh pemerintah daerah melalui perundangundangan. Penelitian ini menggunakan Peraturan Gubernur Sumatera Selatan No.16 Tahun 2015 yang berisi Peruntukan Air dan Baku Mutu Air Sungai sebagai dasar penetapan kualitas air Sungai Sekanak.

Terdapat 3 (tiga) kelompok tolak ukur kualitas air dari suatu sistem perairan, yaitu fisika, kimia, dan biologi. Parameter fisika terdiri dari suhu, turbiditas dan total padatan larutan. Adapun parameter kimia meliputi pH, oksigen terlarut/Dissolved Oxygen (DO), kebutuhan oksigen hayati (BOD), kebutuhan oksigen kimiawi (COD) dan nitrat. Sedangkan parameter biologi antara lain keberadaan plankton, bakteri dan sebagainya. TSS, TDS, BOD, COD, dan DO merupakan parameter kunci untuk melihat tingkat pencemaran suatu perairan, terutama yang disebabkan oleh limbah organic. Misalnya limbah cair yang dihasilkan agroindustri, bahan organik buangan rumah tangga atau permukiman yang masuk ke perairan umum (Manik, 2016).

\section{Metode Penelitian \\ 3.1 Lokasi dan Waktu Penelitian}

Pelaksanaan penelitian dilakukan sejak bulan Februari hingga Agustus tahun 2018. Secara administratif, penelitian ini dilakukan di lingkup kelurahan yang dilewati oleh aliran Sungai Sekanak yaitu Bukit Baru, Bukit Lama, Demang Lebar Daun, Lorok Pakjo, 19 Ilir, 22 Ilir, 23 Ilir, Talang Semut, 24 Ilir, 26 Ilir, dan 27 Ilir. Adapun titik pengambilan sampel kualitas air dapat dilihat pada Tabel 1.

Tabel 1. Titik Koordinat Lokasi Pengambilan Sampel Air Sungai Sekanak

\begin{tabular}{|c|c|c|c|}
\hline \multirow{2}{*}{ No } & \multirow{2}{*}{ Titik Sampling } & \multicolumn{2}{|c|}{ Titik Koordinat } \\
\hline & & $S$ & $E$ \\
\hline 1 & Jl. Tanjung Barangan & 0258'54.68" & 104운'48.56" \\
\hline 2 & $\begin{array}{l}\text { Jl. Demang Lebar } \\
\text { Daun }\end{array}$ & $02^{\circ} 59^{\prime} 02.33^{\prime \prime}$ & $104^{\circ}-43^{\prime} 22.53^{\prime \prime}$ \\
\hline 3 & Belakang Polsri & $02^{\circ} 58^{\prime} 52.52^{\prime \prime}$ & 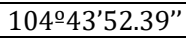 \\
\hline 4 & Jl. Letnan Mukmin & 0258'51.08' & 1044'15.83" \\
\hline 5 & Jl.Radial & 025'51.48' & 104운도.32" \\
\hline 6 & Kel.Talang Semut & 0259'18.89"' & 104ㄴㄷ'15.45” \\
\hline 7 & Muara & 02-59'39.72"' & 104 -45'26.32" \\
\hline
\end{tabular}

\subsection{Metode Pengumpulan Data}

Penelitian ini menggunakan jenis data primer dan sekunder. Teknik pengumpulan data primer dilakukan dengan menggunakan kuesioner, wawancara dan observasi lapangan. Adapun data sekunder diperoleh dari berbagai literatur, laporan hasil penelitian terdahulu, laporan kegiatan dan data statistik hasil pengukuran yang dikeluarkan oleh instansi-instansi terkait. Selain itu, untuk mengetahui pengaruh perilaku masyarakat terhadap kualitas air, maka digunakan teknik triangulasi sumber data dimana selain menggunakan kuesioner, wawancara dan observasi, penulis juga menggunakan literatur dan penelitian terdahulu sebagai sumber dalam analisis data.

\subsection{Analisa Data}

\subsubsection{Identifikasi PHBS dan Sanitasi}

Untuk menjawab tujuan penelitian yang pertama yaitu mengidentifikasi perilaku sanitasi dan PHBS masyarakat, data yang digunakan adalah data primer yang diperoleh dari kuesioner. Sebelum dianalisis lebih lanjut, dilakukan uji validitas dan reabilitas terhadap kuesioner sebagai instrumen 
sebelum data dianalisis lebih lanjut. Kedua uji dilakukan menggunakan alat analisis SPSS dimana untuk uji validitas menggunakan uji Rank Spearman, sedangkan uji reabilitas menggunakan uji Cronbach Alpha.

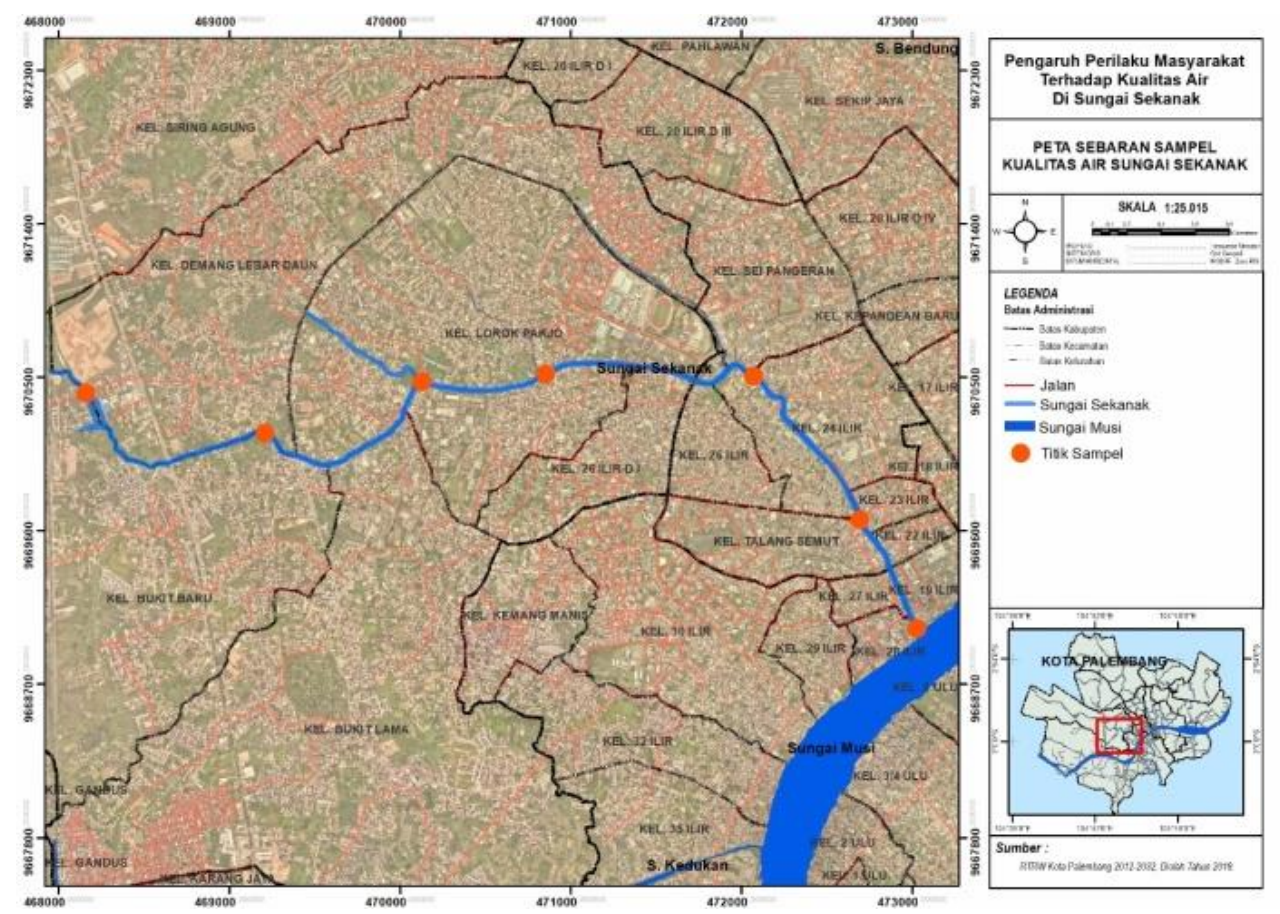

Gambar 1. Lokasi Pengambilan Sampel

Analisis data yang digunakan untuk mengidentifikasi perilaku masyarakat adalah deskriptif kuantitatif dimana jawaban pada kuesioner memiliki bobot dan penilaian yang dapat ditentukan berdasarkan interval kelas. Skala yang digunakan dalam penelitian ini adalah skala Likert (Sugiyono, 2010). Kategori penilaian baik, sedang dan kurang dengan definisi sesuai pada Tabel 2 berikut.

Tabel 2. Kategori Penilaian Berdasarkan Persentase Jawaban Responden

\begin{tabular}{lll}
\hline No. & Kategori Jawaban & Kategori \\
\hline 1 & $1.00-1.80$ & Sangat rendah \\
\hline 2 & $1.81-2.60$ & rendah \\
\hline & $2.61-3.40$ & Cukup \\
\hline 3 & $3.41-4.20$ & Tinggi \\
\hline
\end{tabular}

Sumber data Notoatmodjo (2003)

\subsubsection{Penentuan Status Mutu Air}

Untuk menjawab tujuan kedua yaitu menganalisis kualitas air Sungai Sekanak dilakukan di tujuh titik pantau sebagai titik pengambilan sampel air sungai dengan membagi menjadi dua segmen pada tiap titik pantau. Penentuan titik pantau sebagai titik pengambilan sampel air sungai menggunakan metode purposive sampling berdasarkan pada kemudahan akses, biaya maupun waktu dalam penelitian ini. Metode pengambilan air sungai dilakukan secara langsung menggunakan metode grab sampling yaitu metode pengambilan sampel sesaat yang menunjukkan karakteristik air hanya pada saat itu sesuai dengan SNI 6989.59:2008. Parameter yang dianalisis meliputi parameter fisika, kimia organik dan mikrobiologi.
Analisis kualitas air Sungai Sekanak menggunakan kriteria mutu air berdasarkan kelas I yang terdapat pada Peraturan Gubernur Sumsel No.16 Tahun 2005 tentang Baku Mutu Air Sungai dan Limbah Cair. Adapun status mutu air menggunakan metode Pollution Index (IP) atau Indeks Pencemaran sesuai dengan Keputusan Menteri Lingkungan Hidup No.115 Tahun 2003. Hasil penilaian menggunakan metode IP bertujuan untuk menilai kualitas air berdasarkan peruntukan tertentu. Selain itu, nilai tersebut dapat menjadi rujukan dalam membenahi kualitas perairan yang tercemar. Persamaan yang digunakan dalam perhitungan nilai IP adalah sebagai berikut:

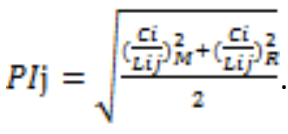

Dimana:

PIj : indeks pencemaran bagi peruntukan (j)

Lij : konsentrasi parameter kualitas air yang dicantumkan dalam Baku Mutu Air (j)

Ci : konsentrasi parameter kualitas air (i)

Dengan $(\mathrm{Ci} / \mathrm{Lij})_{\mathrm{R}}$ : nilai, Ci/Lij rata-rata dan $(\mathrm{Ci} / \mathrm{Lij})_{\mathrm{M}}$ : nilai, Ci/Lij maksimum.

\subsubsection{Pengaruh Perilaku Masyarakat terhadap Kualitas Air Sungai}

Menjawab tujuan penelitian untuk menganalisis pengaruh perilaku masyarakat terhadap kualitas air digunakan metode kualitatif deskriptif yaitu menggambarkan dan menganalisis berbagai data dan temuan yang diperoleh dari sebelumnya, antara lain: hasil kuesioner, uji kualitas air, wawancara mendalam, dan pelbagai literatur. Selanjutnya, 
dilakukan penjabaran dalam bentuk penjelasaan yang konkrit.

\section{Hasil dan Pembahasan}

\subsection{Deskripsi Perilaku Masyarakat \\ 4.1.1 Pengetahuan}

Hasil analisis uji frequencies dapat dilihat pada Diagram 2 dimana lebih dari 50\% jumlah responden telah menunjukkan pengetahuan yang baik tentang bagaimana mengelola sampah yang benar dan sanitasi yang baik. Masyarakat telah mengetahui pentingnya menjaga kebersihan sungai dan lingkungan. Selain itu, penggunaan air bersih untuk konsumsi dan kegiatan MCK pribadi menggunakan air PDAM telah dilakukan oleh hampir semua responden.

Hasil penelitian ini sesuai dengan studi Eilam dan Trop (2012) bahwa beberapa faktor yang dapat mempengaruhi pengetahuan individu salah satunya adalah pendidikan. Sekitar 50 persen tingkat pendidikan masyarakat di bantaran Sungai Sekanak berada pada tingkat menengah ke atas yaitu tamat SMA dan pendidikan tinggi, sedangkan sisanya masih tergolong rendah. Pendidikan adalah proses merubah sikap dan perilaku seseorang atau sekelompok orang. Pengetahuan memiliki peran penting dalam mempengaruhi perilaku seseorang dalam kegiatan sehari-harinya, terutama dalam hal penerimaan segala sesuatu melalui media atau yang disampaikan secara langsung. Berdasarkan Silgo et al. (2007) bahwa jika perilaku yang baru terbentuk atau perilaku yang diadopsi didasarkan pada pengetahuan, kesadaran dan sikap yang baik, maka perilaku tersebut sifatnya akan bertahan lama dan sebaliknya. Oleh karena itu, responden yang memiliki tingkat pendidikan yang rendah diharapkan dapat ditingkatkan pengetahuannya dalam pelestarian sungai melalui kegiatan sosialisasi atau penyuluhan.

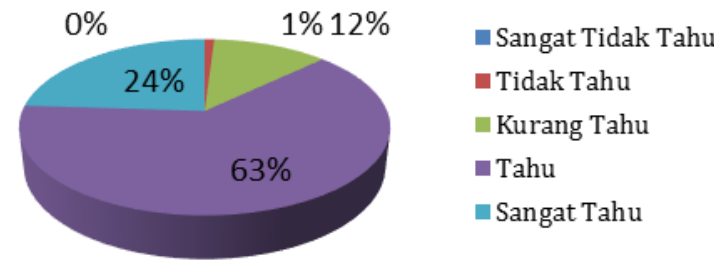

Gambar 2. Pengetahuan Masyarakat terhadap PHBS dan Sanitasi

\subsubsection{Sikap}

Menurut Notoatmodjo (2010) sikap masyarakat dipengaruhi oleh tingkat pengetahuannya. Adapun sikap mempengaruhi perilaku seseorang, tapi tidak secara otomatis direalisasikan pada tindakan karena terdapat faktor-faktor pendukung lain yang dibutuhkan antara lain: fasilitas, pengalaman, motivasi dan lingkungan (Sunarto, et al, 2014). Stone et al (2010) menyatakan bahwa sikap merupakan suatu kecenderungan untuk merespons secara negative atau positif terhadap suatu objek menggunakan pendekatan persuasif, baik model individu ataupun masyarakat. Dengan kata lain, untuk mengubah sikap masyarakat diperlukan pendekatan persuasif yang dilakukan individu atau institusi sebagai contoh sukses bagi masyarakat.

Sikap masyarakat rata-rata sangat baik dalam penerimaan dan merespon kegiatan PHBS dan sanitasi seperti terlihat pada Gambar 3. Sikap penerimaan masyarakat terhadap kegiatan PHBS dan sanitasi terbentuk berdasarkan norma subjektif yaitu motivasi individual untuk mengikuti atau mematuhi orang lain. Berdasarkan faktor norma subjektif ini, maka kepatuhan masyarakat untuk melestarikan sungai dan lingkungan dapat dilakukan secara spontan karena keyakinan normatif (normative beliefs). Bagi masyarakat yang tinggal di bantaran Sungai Sekanak, keyakinan normatif ini dapat diperoleh dari tokoh-tokoh masyarakat dan instansi terkait yang menjadi panutan dan memiliki kemampuan persuasif untuk mendorong masyarakat terlibat aktif dalam kegiatan pelestarian sungai (Burton, 2007).

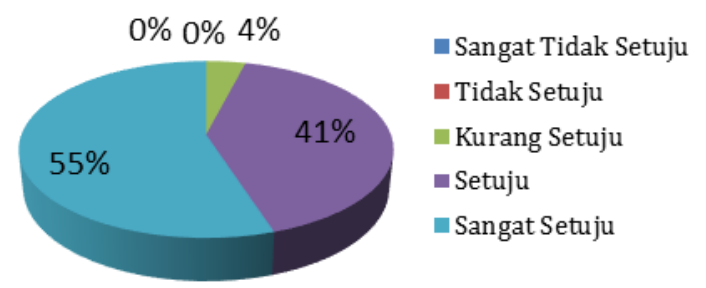

Gambar 3. Sikap Masyarakat terhadap Kegiatan PHBS dan Sanitasi

\subsubsection{Tindakan}

Hasil kuesioner terhadap tindakan masyarakat bantaran Sungai Sekanak menunjukkan bahwa 80 persen masyarakat telah rutin melakukan kegiatan PHBS dan sanitasi, antara lain tidak membuang sampah ke sungai dan rutin menjaga kebersihan lingkungan di sekitar rumah, menggunakan MCK pribadi dan mengkonsumsi air bersih. Namun, sekitar 20 persen responden belum rutin menerapkan PHBS dengan masih membuang sampah ke sungai dan belum mengelola sampah dengan baik (Gambar 4) terutama oleh warga di Kelurahan Lorok Pakjo. Ini artinya terdapat masyarakat yang masih belum mengimplementasikan pengetahuannya dalam kegiatan PHBS dan sanitasi dalam kegiatan sehari-hari. Tindakan masyarakat tersebut dalam pengelolaan sampah ialah pembentuk perilaku yang paling lemah karena mereka belum mampu menerapkan pengetahuan yang didapatkan tentang konservasi sungai dan pengelolaan sampah yang benar

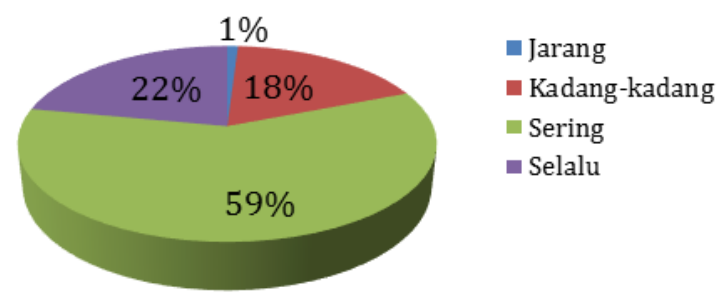

Gambar 2. Tindakan Masyarakat terhadap PHBS dan Sanitasi 
Tindakan masyarakat yang tinggal di bantaran Sungai Sekanak dibentuk berdasarkan faktor keyakinan perilaku (behavioural beliefs) yaitu keyakinan yang diperoleh dari pengetahuan atau pengalaman tentang nilai positif dari kegiatan PHBS dan sanitasi (Ajzen, 2002). Selain itu, menurut Eagly dan Chaiken (1993) terdapat faktor-faktor lain yang dapat memprediksi intensi dan perilaku individu atau warga, antara lain: variabel kebiasaan (habit), persepsi mengenai kewajiban moral, dan self-identity. Faktor keyakinan perilaku dapat lebih kuat berpengaruh melalui sikap terhadap faktor-faktor perilaku artinya munculnya sikap untuk mengimplementasikan kegiatan PHBS dan sanitasi dengan persepsi bahwa penerapannya pada Sungai Sekanak akan berdampak baik bagi kebersihan dan pelestarian lingkungan. Kesadaran konservasi tersebut dapat ditumbuhkan sejak dini melalui pendidikan moral dan akhlak terhadap lingkungan.

Motivasi dan niat individu atau masyarakat untuk membuang sampah di dekat sungai atau secara langsung ke badan sungai dibentuk dari keyakinan control (control beliefs) yaitu keyakinan bahwa individu mampu melakukan tindakan karena didukung oleh sesuatu yang dapat memfasilitasinya untuk membuang sampah ke sungai secara spontan yaitu arus pasang surut sungai yang dianggap dapat membersihkan sampah termasuk meletakkan timbunan sampah di pinggiran sungai. Penyebab adanya timbunan sampah di sekitar sungai ini akan diperkuat dengan adanya faktor perceived behavioural control yaitu persepsi mengenai kesulitan atau kemudahan untuk berperilaku dan dianggap merefleksikan pengalaman di masa lalu (Ajzen, 2002).

\subsection{Analisis Kualitas Air Sungai Sekanak}

Pengambilan sampel air untuk menguji kualitas air Sungai Sekanak dilakukan di tujuh titik pantau yang berbeda disepanjang Sungai Sekanak mulai dari ujung hulu hingga dekat dengan muara sungai. Pengambilan sampel air tersebut dilakukan satu kali berdasarkan metode grab sampling sesuai dengan SNI 6989.59:2008 pada bulan Februari 2018 di saat air sungai sedang pasang.

Selanjutnya sampel air langsung diserahkan pada Laboratorium Dinas Lingkungan Hidup dan Kebersihan Kota Palembang untuk diuji kualitasnya dengan parameter fisika (Suhu, TSS), kimia organik (pH, BOD, COD, Nitrat, Nitrit, Amonia, Phospat) dan mikrobiologi (total Coliform). Kemudian hasil uji lab kualitas air Sungai Sekanak di setiap titik pantau dibandingkan dengan baku mutu air yang berlaku. Peruntukan Sungai Sekanak berdasarkan Peraturan Gubernur Sumatera Selatan No.16 Tahun 2005 tentang Baku Mutu Air Sungai dan Limbah Cair ditetapkan sebagai baku mutu air kelas I. Peruntukan klasifikasi mutu air kelas I ini dapat digunakan untuk mutu baku air minum, dan atau peruntukan lain yang mempersyaratkan mutu air yang sama dengan kegunaan tersebut. Berikut adalah hasil pengukuran kualitas air pada 7 (Tujuh) titik pantau yang berbeda yang disajikan pada Tabel 5.3.

Hasil analisa kualitas air pada Tabel 5.3 mengindikasikan beberapa parameter sebagai berikut:

a. $\mathrm{pH}$

Hasil pengukuran pH air Sungai Sekanak menunjukkan bahwa rata-rata $\mathrm{pH}$ pada titik pantau II hingga VII berada pada $\mathrm{pH}$ yang normal sesuai dengan baku mutu air kelas I yaitu antara 6 - 9 . Sedangkan pada titik pantau I pH berada di bawah 6 yang bersifat cenderung asam. Titik tersebut terletak di Tanjung Barangan yang merupakan daerah rawa konservasi yang tidak boleh dibangun apapun di atasnya, sehingga menyebabkan air sungai menjadi cukup masam.

b. Suhu

Hasil pengukuran suhu air Sungai Sekanak pada titik pantau I hingga VII membuktikan bahwa suhu air rata-rata berada pada suhu $27^{\circ} \mathrm{C}$. Nilai tersebut menunjukkan bahwa kriteria mutu air Sungai Sekanak untuk parameter suhu masih sesuai dengan peruntukkannya yaitu berada di bawah deviasi 3 .

Tabel 3. Hasil Pengukuran Kualitas Air Sungai Sekanak

\begin{tabular}{|c|c|c|c|c|c|c|c|c|c|}
\hline \multirow[b]{2}{*}{ Parameter } & \multirow[b]{2}{*}{ Satuan } & \multicolumn{7}{|c|}{ Lokasi Pengambilan Sampel } & \multirow[b]{2}{*}{$\begin{array}{l}\text { Baku Mutu } \\
\text { Air Kelas I }\end{array}$} \\
\hline & & Titik I & Titik II & Titik III & Titik IV & Titik V & Titik VI & $\begin{array}{c}\text { Titik } \\
\text { VII }\end{array}$ & \\
\hline $\mathrm{Ph}$ & - & 5,07 & 7,18 & 6,92 & 7,20 & 7,50 & 7,30 & 7,23 & $6-9$ \\
\hline Suhu & ${ }^{\circ} \mathrm{C}$ & 27,3 & 27,1 & 27,1 & 27,1 & 27,1 & 27,0 & 27,0 & Deviasi 3 \\
\hline TSS & $\mathrm{mg} / \mathrm{l}$ & 49 & 51 & 31 & 98 & 19 & 29 & 22 & 50 \\
\hline TDS & $\mathrm{mg} / \mathrm{l}$ & 19,25 & 116,7 & 122,8 & 130,3 & 179,5 & 159,5 & 76,2 & 1000 \\
\hline COD & $\mathrm{mg} / \mathrm{l}$ & 12,69 & 48,54 & 49,31 & 44,39 & 38,0 & 52,83 & 13,95 & 10 \\
\hline $\mathrm{BOD}_{5}$ & $\mathrm{mg} / \mathrm{l}$ & 2,79 & 10,68 & 10,85 & 9,76 & 8,36 & 11,62 & 3,06 & 2 \\
\hline Nitrit & $\mathrm{mg} / \mathrm{l}$ & 1,3 & 1,0 & 0,8 & 1,0 & 0,7 & 1,0 & 1,4 & 10 \\
\hline Nitrat & $\mathrm{mg} / \mathrm{l}$ & 0,034 & 0,018 & 0,016 & 0,018 & 0,009 & 0,009 & 0,048 & 0,06 \\
\hline $\mathrm{NH}_{3}-\mathrm{N}$ & $\mathrm{mg} / \mathrm{l}$ & 0,05 & 0,74 & 2,49 & 0,73 & 2,07 & 2,34 & 1,235 & 0,5 \\
\hline Phosfat & $\mathrm{mg} / \mathrm{l}$ & 2,36 & 2,47 & 2,49 & 1,56 & 2,41 & 2,40 & 0,33 & 0,2 \\
\hline $\begin{array}{l}\text { Total } \\
\text { Coliform }\end{array}$ & $\begin{array}{l}\mathrm{MPN} / 10 \\
0 \mathrm{ml}\end{array}$ & 23 & 64 & 43 & 74 & 43 & 64 & 35 & 1000 \\
\hline
\end{tabular}

Sumber: Hasil Analisis Laboratorium DLHK Kota Palembang 2018

\section{c. TSS \& TDS}

Nilai Padatan Tersuspensi (TSS) pada lokasi titik pantau II dan IV telah melampaui batas baku mutu air Kelas I Pergub Sumsel No.16 Tahun 2005 yaitu lebih dari $50 \mathrm{mg} /$ liter dengan nilai tertinggi pada titik pantau IV. Nilai TSS dipengaruhi oleh 
tingkat sedimen yang tersuspensi dalam perairan. Sedimentasi yang tinggi di sekitar sungai, dan tingginya aktivitas warga di sekitar sungai berpengaruh erat terhadap penurunan kualitas fisik perairan sungai. Di Titik Pantau IV yang berlokasi di Jalan Letnan Mukmin telah terjadi konversi lahan yang masif dari permukiman dan ruang terbuka hijau

Nilai Padatan Terlarut Total (TDS) dari seluruh titik pantau berada pada rentang 19,25 hingga 179,5 mg/liter. Konsentrasi TDS tersebut menunjukkan bahwa jumlah residu terlarut dalam perairan masih memenuhi standar baku mutu air sungai yang ditetapkan, yaitu kurang dari 1000 mg/liter.

d. COD (Chemical Oxygen Demand)

Konsentrasi COD yang tinggi mengindikasikan semakin besar tingkat pencemaran yang terjadi pada suatu perairan. Hasil pengukuran COD pada lokasi titik pantau I -VII telah melampaui ambang batas baku mutu air yang ditetapkan (10 mg/liter) yaitu berkisar antara 12,69 - 52,83. Tingkat COD akan berbeda di sepanjang aliran sungai, akan tetapi tingkatnya akan meningkat signifikan jika terdapat aliran limbah domestik dan tumpukan sampah. Titik lokasi pantau VI memiliki nilai COD tertinggi berlokasi di Kelurahan Talang Semut yang padat penduduk di mana limbah buangan rumah tangga langsung dialirkan ke sungai.

\section{e. $\mathrm{BOD}_{5}$ (Biological Oxigen Demand)}

Hasil analisa pengukuran BOD pada seluruh lokasi titik pantau menunjukkan bahwa nilai BOD tidak sesuai dengan baku mutu kualitas air yaitu lebih dari $2 \mathrm{mg} /$ liter berdasarkan Kriteria Kelas I Air Sungai menurut Pergub Sumsel No.16 Tahun 2005. Nilai tertinggi juga berada pada lokasi titik pantau VI yaitu mencapai 11,62 mg/liter. Meningkatnya konsentrasi BOD pada suatu perairan merupakan indikasi terjadinya pencemaran oleh bahan organik dimana salah satu penyumbangnya berasal dari limbah domestik.

f. Nitrit $\left(\mathrm{NO}_{3}-\mathrm{N}\right)$ dan Nitrat $\left(\mathrm{NO}_{2}-\mathrm{N}\right)$

Hasil analisa parameter Nitrit dan Nitrat pada seluruh titik pantau memperlihatkan masih berada pada ambang batas Kriteria Kelas I Air Sungai menurut Pergub Sumsel No.16 Tahun 2005. Merujuk pada Effendi (2003) nilai kandungan nitrat tidak pernah lebih dari $0,1 \mathrm{mg} /$ liter pada perairan alami. Hasil uji kualitas air sungai yang dapat dilihat pada Tabel 3 mengungkapkan kandungan nitrat di seluruh titik pantau berkisar antara 0,009 hingga 0,048 mg/liter artinya masih berada pada kondisi alamiahnya.

Hasil sebaran kandungan nitrit pada Sungai Sekanak seperti pada Tabel 3 berkisar antara 0,7 $1,4 \mathrm{mg} /$ liter. Sementara itu, konsentrasi nitrit pada perairan alami sebesar $0,001 \mathrm{mg} / \mathrm{liter}$ dan memiliki ambang batas sebesar $0,06 \mathrm{mg} /$ liter. Hasil tersebut mengindikasikan bahwa air Sungai Sekanak sudah tidak berada pada kondisi alamiahnya, namun nilai tersebut belum melampaui baku mutu air sungai yang ditetapkan. Adapun sumber pencemar yang mengandung nitrit dapat berasal dari limbah industri dan limbah domestik.

\section{g. $\mathrm{NH}_{3}-\mathrm{N}$ (Amoniak)}

Hasil pengukuran kadar amoniak pada titik pantau I menunjukkan masih berada dibawah ambang baku mutu air yang ditetapkan karena beban pencemaran yang diakibatkan oleh limbah permukiman masih minim di lokasi tersebut yang di sekitarnya masih didominasi rawa dan permukiman warga masih belum padat. Sebaliknya, hasil analisis pada titik pantau II hingga VII telah melebihi baku mutu air sungai Kelas I Pergub Sumsel No.16 Tahun 2005 yaitu berada pada nilai 0,73 - 2,49 mg/liter. Kadar amonia pada perairan alami biasanya kurang dari 0,1 mg/l. Kandungan amoniak yang melebihi baku mutu memperlihatkan adanya kandungan bahan organik yang merupakan kontribusi dari limbah industri, domestik, maupun limpasan pupuk pertanian (Effendi, 2003).

g. Fosfat

Hasil pengukuran kandungan phospat di seluruh titik pantau diperoleh kandungan sebesar 0,33 hingga 2,49 mg/liter lebih tinggi melampaui standar kriteria baku mutu sebesar 0,2 mg/l, sehingga tidak sesuai dengan peruntukkanya. Air buangan limbah rumah tangga seperti deterjen dapat menjadi sumber pencemar yang mengakibatkan tingginya nilai fosfat (Effendi, 2003).

\section{h. Total Coliform}

Keberadaan bakteri coliform dapat menentukan keberadaan kontaminan yang berasal dari buangan rumah tangga. Menurut Chapra (1997) bakteri ini dapat menularkan jenis penyakit tertentu utamanya penyebab terjadinya penyakit pada perut, antara lain: disentri, tipus dan kolera.

Merujuk pada Tabel 3 jumlah bakteri total coliform jika dibandingkan dengan standard baku mutu air masih jauh di bawah ambang batas kriteria, sehingga masih sesuai untuk peruntukannya masih.

\subsection{Analisis Status Mutu Air Sungai Sekanak}

Merujuk pada Keputusan Menteri Lingkungan Hidup No.115 Tahun 2003 tentang penentuan status mutu air yang diijinkan yaitu salah satunya mengunakan metode Indeks Pencemaran. Penentuan kualitas air menggunakan Indeks Pencemaran (IP) ini bermanfaat sebagai masukan bagi otoritas terkait dalam memberikan penilaian kualitas badan air untuk suatu peruntukan. Di samping itu, berdasarkan hasil penilaian tersebut dapat dirumuskan tindakan untuk mengatasi degradasi kualitas lingkungan yang disebabkan oleh senyawa pencemar.

Pengelolaan kualitas air atas dasar Indeks Pencemaran (IP) ini dapat memberi masukan pada pengambil keputusan agar dapat menilai kualitas badan air untuk suatu peruntukan serta melakukan tindakan untuk memperbaiki kualitas jika terjadi penurunan kualitas akibat kehadiran senyawa pencemar. Berikut hasil perhitungan status mutu air pada tujuh lokasi pengambilan sampel di Sungai Sekanak: 
Tabel 4 Status Mutu Air Sungai Sekanak

\begin{tabular}{|c|c|c|c|c|}
\hline \multirow{2}{*}{$\begin{array}{c}\text { Titik } \\
\text { Sampling }\end{array}$} & \multicolumn{2}{|c|}{$\mathrm{Ci} / \mathrm{Lij}$} & \multirow{2}{*}{$\begin{array}{l}\text { Nilai Indeks } \\
\text { Pencemaran }\end{array}$} & \multirow{2}{*}{ Status Mutu } \\
\hline & Maks & Rerata & & \\
\hline I & 6,36 & 1,30 & 4,59 & Cemar Ringan \\
\hline II & 6,46 & 1,92 & 4,76 & Cemar Ringan \\
\hline III & 6,48 & 2,16 & 4,83 & Cemar Ringan \\
\hline IV & 5,46 & 1,92 & 4,09 & Cemar Ringan \\
\hline $\mathrm{V}$ & 6,40 & 1,93 & 4,73 & Cemar Ringan \\
\hline VI & 6,40 & 2,14 & 4,77 & Cemar Ringan \\
\hline VII & 2,96 & 1,04 & 2,22 & Cemar Ringan \\
\hline
\end{tabular}

Hasil penilaian status mutu air Sungai Sekanak pada Tabel 4 menunjukkan bahwa status mutu air Sungai Sekanak dari muara hingga ke ujung hulu mengalami kondisi cemar ringan. Akibatnya, kualitas air sungai Sekanak dari hulu ke hilir pada seluruh titik pantau tidak dapat dimanfaatkan sesuai dengan peruntukan air kelas I yaitu untuk air baku air minum, dan atau peruntukan lain yang mempersyaratkan mutu air yang sama dengan kegunaan tersebut, sehingga diperlukan pengendalian Pencemaran air Sungai Sekanak agar dapat dimanfaatkan dan menjaga agar kualitas air Sungai Sekanak tetap sesuai dengan baku mutu air sasaran.

\subsection{Pengaruh Perilaku Masyarakat Terhadap Kualitas Air Sungai Sekanak}

Berdasarkan hasil observasi dan kuesioner, perilaku responden/masyarakat yang tinggal di bantaran Sungai Sekanak masih membuang sampah ke sungai dan atau mengumpulkan timbunan sampah pada TPS-TPS illegal yang berada sangat dekat dengan sungai seperti pada Gambar 5. Keberadaan TPS illegal tersebut mengancam kualitas sungai terutama jika musim penghujan dan sampah sudah menumpuk yang menyebabkan sampah-sampah tersebut akan mengalir ke sungai. Hal ini juga ditunjukkan dengan kandungan nilai COD dan BOD di seluruh titik pengamatan telah melampui baku mutu air. Kurangnya kesadaran masyarakat dan minimnya ketersediaan dan kualitas infrastruktur persampahan yang dekat dengan permukiman warga menjadi pemicu keberadaan TPS ilegal di sekitar Sungai Sekanak

Selain itu, berdasarkan hasil wawancara dan kuesioner di lapangan, rata-rata masyarakat yang tinggal di bantaran Sungai Sekanak telah memiliki WC pribadi. Akan tetapi, hasil observasi di titik pengamatan 4 hingga 6 masih ditemui perilaku masyarakat mencuci dan membuang sisa makanan dagangan ke sungai. Selain itu, keberadaan Pasar Sekanak yang berada tepat di pinggir sungai pada titik pengamatan 7 juga memiliki kontribusi terjadinya pencemaran limbah organik dan air limbah dari aktivitas perdagangan.

Perilaku masyarakat yang membuang air limbah domestik langsung ke badan sungai yang dapat dilihat dari aliran drainase yang berasal dari rumah-rumah warga pada Gambar 6. Selain mempengaruhi kandungan COD dan BOD, perilaku masyarakat tersebut mempengaruhi parameter amoniak yang melebihi baku mutu pada titik pengamatan 2 hingga 7. Belum tersedianya fasilitas Instalasi Pembuangan Air Limbah (IPAL) Komunal di kawasan bantaran sungai menyebabkan tingginya beberapa parameter kimia tersebut. Teknologi IPAL ini sangat penting guna menurunkan beban pencemar yang ada di sungai.

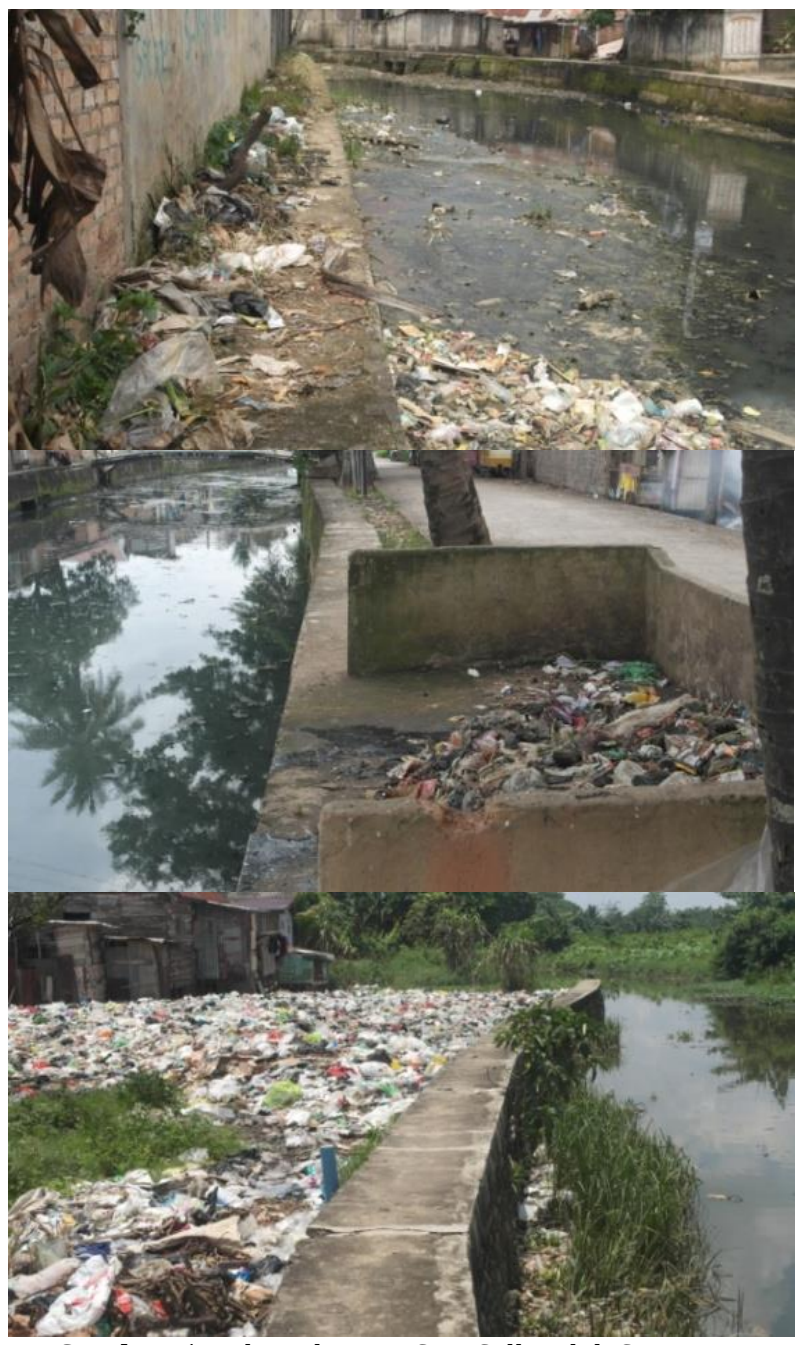

Gambar 5. Keberadaan TPS-TPS illegal di Sepanjang Sungai Sekanak

Selain itu, parameter kimia yang melebihi nilai baku adalah Nitrat dan Fosfat. Tingginya nilai Fosfat menunjukkan adanya kandungan deterjen dalam air yang merupakan salah satu indikator dari adanya pencemaran sungai dari kegiatan MCK warga. Adapun nitrat merupakan bentuk utama nitrogen di perairan alami dan merupakan sumber utama bagi perkembangan algae dan tumbuhan air (Effendi, 2003). Kadar nitrat yang melebihi baku mutu seperti pada lokasi 1 dan 2 yaitu 10,64 mg/l merupakan gambaran dari adanya pencemaran perairan oleh aktifitas manusia, sisa pupuk, dan tinja hewan. Mengonsumsi air dengan kadar Nitrat tinggi akan menyebabkan menurunnya kapasitas darah yang berfungsi untuk mengikat oksigen, sehingga akan cukup membahayakan manusia terutama bayi dibawah 5 bulan karena akan menyebabkan blue baby disease (Davis dan Cornwell, 1991). Untuk keperluan air minum, kadar nitrat diharapkan tidak lebih dari $10 \mathrm{mg} / \mathrm{l}$ (Effendi, 2003).. 

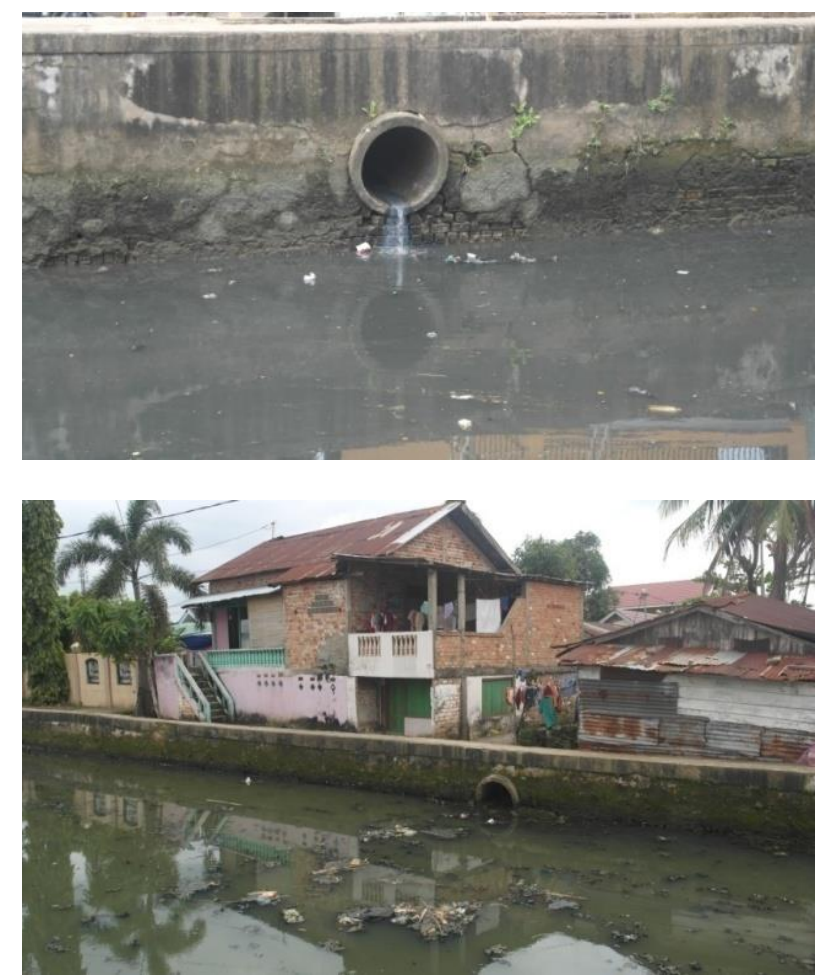

Gambar 6. Aliran Saluran Drainase (Parit) dari Permukiman Warga

Program pemerintah untuk merestorasi Sungai Sekanak telah direncanakan sejak Tahun 2016 dan mulai dilakukan persiapan pengerjaan sejak awal tahun 2018. Program restorasi ini dilakukan dengan menggali sedalam 2 meter Sungai Sekanak hingga Sungai Lambidaro, sehingga air pasang surut dari Sungai Musi dapat masuk ke anakanak sungai tersebut. Pada Tabel kualitas air di titik pantau ke VII dekat muara dapat dilihat bahwa nilai pencemaran yang terjadi lebih rendah dari titik pantau lainnya. Hal ini karena proses pengerukan sungai sudah mulai dilakukan dari muara hingga ke jembatan Sekanak yang dapat dilihat pada Gambar 5.9.

Langkah revitalisasi tersebut tentunya tidak hanya dapat dilakukan secara teknis, tetapi harus ditunjang melalui pembenahan aspek sosio-ekologis sebagai komponen penting dalam strategi pelestarian lingkungan untuk jangka panjang. Peningkatan kesadaran, kemampuan dan partisipasi masyarakat yang tinggal di bantaran Sungai Sekanak terhadap pelestarian sungai menjadi tantangan tersendiri yang terkait dengan pendidikan, pelatihan dan penyuluhan masyarakat. Hal ini bertujuan untuk mendorong masyarakat agar dapat mengembangkan kemampuan berpikir kritis, etis dan kreatif dalam menilai situasi lingkungan dan membuat keputusan tentang situasi tersebut. Selain itu, melalui pendidikan lingkungan masyarakat diharapkan dapat mengembangkan kapasitas dan komitmen untuk bertindak secara individual dan kolektif dalam rangka menjaga dan meningkatkan kualitas lingkungan.
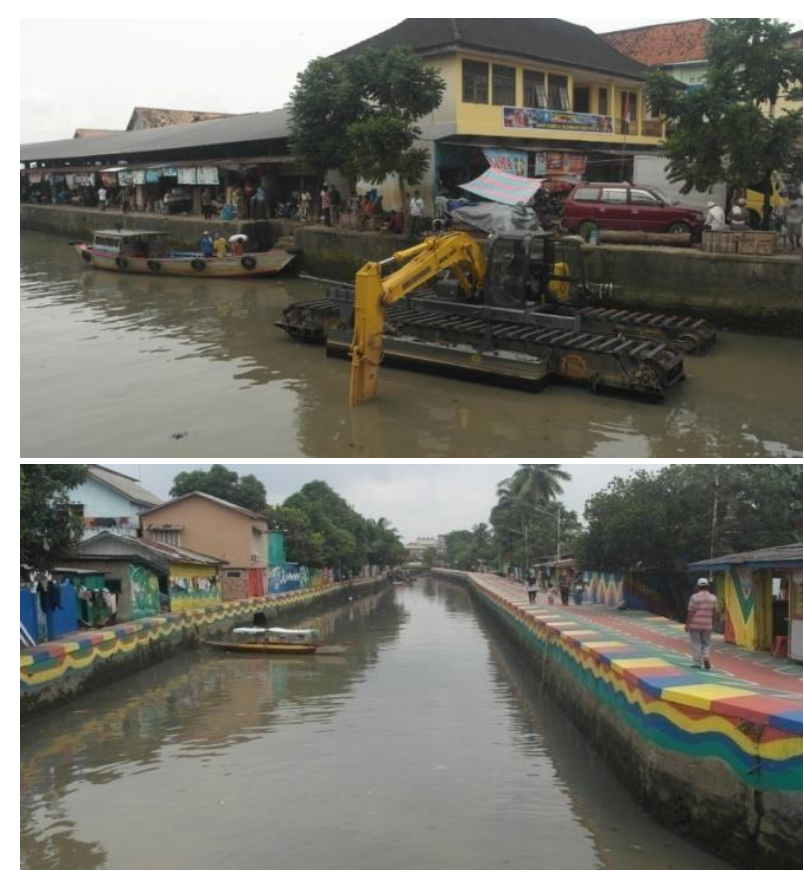

Gambar 7. Proses Restorasi Sungai Sekanak

\section{Kesimpulan}

Hasil penelitian ini dapat disimpulkan bahwa:

1. Terdapat pengaruh perilaku masyarakat terhadap penurunan kualitas air Sungai Sekanak yaitu akibat pencemaran air limbah domestik dan industri yang tanpa diolah terlebih dahulu langsung dialirkan ke sungai ditunjukkan dengan nilai COD, BOD, amoniak dan fosfat di sepanjang aliran sungai telah melampaui baku mutu yang telah ditetapkan.

2. Tingginya aktivitas konversi lahan menyebabkan terjadinya sedimentasi dan mempengaruhi nilai TSS di titik pengamatan IV. Selain itu, tingginya nilai fosfat menjadi indikator adanya kandungan deterjen di dalam air yang berasal dari kegiatan MCK warga.

3. Kebiasaan masyarakat di sekitar sungai yang membuang sampah sembarangan, adanya TPSTPS ilegal yang berada di pinggiran sungai, serta belum tersedianya fasilitas IPAL komunal untuk mengolah limbah domestik dari rumah-rumah warga menyebabkan Sungai Sekanak masih terus tercemar.

\section{UCAPAN TERIMA KASIH}

Ucapan terima kasih yang sedalam-dalamnya Kami ucapkan kepada :

1. Kementerian Riset, Teknologi, dan Pendidikan Tingi selaku penyedia dana hibah Penelitian Dosen Pemula

2. Ketua dan staff Lembaga Penelitian dan Pengabdian Kepada Masyarakat (LPPM) UIGM atas dukungan yang diberikan.

3. Seluruh pimpinan dan rekan-rekan di Universitas Indo Global Mandiri atas bantuan yang diberikan. 
4. Keluarga atas doa dan support yang selalu diberikan.

5. Pihak-pihak terkait yang membantu tersedianya data dalam penelitian ini.

\section{DAFTAR PUSTAKA}

Ajzen. 2002. Perceived Behavioural Control, Selfefficacy, Locus of Control, and the Theory of Planned Behaviour. J. Appl. Soc. Psychol., Vol.32 No.4, 665683.

Badan Lingkungan Hidup (BLH) Kota Palembang. 2012. Laporan Sungai Anak Sungai Kota Palembang. https://www.academia.edu/9773539/Laporan_Sung ai_Anak_sungai_Kota_Palembang_2012. diakses tanggal 30 Mei 2017.

Burton, M., Marsh, S., Patterson, J. 2007. Community Attitudes towards Water Management in the Moore Catchment, Western Australia. Agricultural System, 92.

Chapra, S. C., 1997. Surface Water Quality

Dinas Lingkungan Hidup dan Kebersihan Kota Palembang. 2017. Laporan Pelaksanaan Pemantauan/Kajian Kualitas Air Sungai dan Anak Sungai dalam Wilayah Kota Palembang Tahun 2017.

Depkes RI. 2007. Profil Kesehatan Indonesia. Jakarta.

Eagly, A.H., \& Chaike, S. (1993). The Pscychology of Attitudes. New York: Harcourt, Brace \& Janovich.

Effendi, H. 2003. Telaah Kualitas Air: Bagi Pengelolaan Sumber Daya Alam dan Lingkungan Perairan. Kanisius: Yogyakarta.

Eilam, E., dan Trop, T. 2012. Factors Influencing Adults' Environmental Attitudes and Behaviour and The Roleh of Environmental Schools in Influencing Their Communities. Educ. Urban Soc., June, 1-30.

Fitriyana, I. 2004. Kualitas Perairan Sungai Citarum Berdasarkan Indeks Biotik. Skripsi. Departemen Konservasi Sumberdaya Hutan. Fakultas Kehutanan. Institut Pertanian Bogor. Bogor.

Inge, N. 2017. Ada Sungai Terapung Di Sungai Kotor Palembang. Liputan 6.com. http://regional.liputan6.com/read/2852783/adapasar-terapung-di-sungai-kotor-palembang. Diakses tanggal 30 Mei 2017.

Manik, K.E.S. 2016. Pengelolaan Lingkungan Hidup. Prenadamedia Group. Jakarta.
Notoatmodjo. 2007. Promosi Kesehatan dan Ilmu Perilaku. Rineka Cipta: Jakarta.

2010. Ilmu Perilaku Kesehatan. Rineka Cipta: Jakarta.

Penny, L., dkk. 2012. Kajian Perilaku Masyarakat Membuang Sampah Di Sempadan Sungai Martapura Terhadap Lingkungan Perairan. Jurnal EnviroScienteae. Vol 8 : 117-126.

Silgo, F.X., Massey, C., 2007. Risk, trust and knowledge networks in farmer' learning. J. Rural Stud., 23, 170 182.

Stone, T. H., Jawahar, I. M., Kisamore, J.L. 2010. Predicting Academic misconduct intentions and behaviour using the Theory of Planned Behaviour and Personality. Basic Appl. Soc. Psychol., 32 (1), 35-45.

Sunarto, S., Bisri, M., Soemarno, Suyadi. 2014. Society Behaviour towards Household Waste Management in Tulungagung. Int. J. Appl. Sociol., 4 (3), 67-73.

Sugiyono. 2009. Metode Penelitian Kuantitatif, Kualitatif dan R\&D. Penerbit Alfabeta Bandung. Bandung.

Supratiwi, F. 2014. 70 Persen Sungai Tercemar Limbah Rumah Tangga. Antaranews.com. http://www.antaranews.com/berita/466480/70persen-sungai-tercemar-limbah-rumah-tangga. Diakses tanggal 3 Juni 2017.

Suriawiria, U. 2003. Air dalam Kehidupan dan Lingkungan yang Sehat. Penerbit Alumni. Bandung.

Susilo, R.K.D. 2012. Sosiologi Lingkungan. PT. Rajagrafindo Persada. Jakarta.

Yohanes S., Subardi, B,M dan Itnawita. 2014. Analisis Total Fosfat, Nitrat dan Logam Timbal pada Sungai Sail dan Sungai Air Hitam Pekanbaru, JOM FMIPA.

Yuliastuti, E. 2011. Kajian Kualitas Air Sungai Ngringo Karanganyar Dalam Upaya Pengendalian Pencemaran Air. Tesis. Program Magister Ilmu Lingkungan. Universitas Diponegoro. Semarang.

\section{Undang-Undang dan Peraturan Pemerintah Lainnya}

Peraturan Gubernur Sumatera Selatan No.16 Tahun 2005 Tentang Peruntukan Air dan Baku Mutu Air Sungai.

Peraturan Menteri Pekerjaan Umum dan Perumahan Rakyat No.28/PRT/M 2015 tentang Penetapan Garis Sempadan Sungai dan Garis Sempadan Danau

Undang-Undang Nomor 7 Tahun 2004 Tentang Sumber Daya Air. 